\title{
Response to Gracia Fay Ellwood's "Religious Experience, Religious Worldviews, and Near-Death Studies"
}

\author{
Michael Sabom, M.D. \\ Atlanta, GA
}

ABSTRACT: After a brief glance at "religious wars" that now embroil the field of near-death studies, I respond to Gracia Fay Ellwood's commentary on Light \& Death (Sabom, 1998), in which she alleges serious problems with my discussion of Raymond Moody's research, my views on the psychic and the occult, my use of the Bible as an authoritative document, my research methodology, and my definition of Christianity.

Gracia Fay Ellwood addresses "religious wars" that have broken out in the study of near-death experiences (NDEs). "[T]ensions have exploded into hostile exchanges," she notes, especially since the publication of "Michael Sabom's recent Light \& Death." In her paper, she presents her view of the history and sociology of religion, followed by a "Commentary" on my book. She alleges "serious problems" with my discussion of Raymond Moody's research, with my views on the psychic and occult, with my use of the Bible as an authoritative document, with my research methodology, and with my definition of Christianity. Before addressing each of these charges, I will first look at the nature and scope of these "religious wars" as they apply to the discussion at hand.

\section{NDE “Religious Wars"}

NDE "wars" are being fought on two levels. On one level, ad hominem attacks are being made between what may roughly be termed orthodox

Michael B. Sabom, M.D., is a cardiologist in private practice. Reprint requests should be addressed to Dr. Sabom at 100 Wing Mill Road, Atlanta, GA 30350 (e-mail: MSabom@aol.com). 
Christian and opposing camps. Maurice Rawlings has accused "Professor Ring and his previous colleagues of the IANDS group" of being in collusion to deny the reality of hell (Rawlings, 1993, p. 113). Moody has renamed Rawlings "Dr. Ravings" and referred to Christian fundamentalists as "goshawful deadfannies, stiffs, bores, nuisances, uptight dogmatists, broken records, and wet blankets; . . 'JAY-zus'-Sayers, Brimfire and Hellstoners, Swaggartists, Falwellers, Bakker-Boosters, Pat Robertsonians, or whatever..." (Moody, 1999, p. x). Richard Abanes has claimed that many NDE researchers have been "raised up by the forces of darkness" (Abanes, 1994, p. 196). And Kenneth Ring has charged me with "recklessness," "blatant distortions," and "paranoia"; has labeled portions of Light \& Death "outlandish," "obviously preposterous," "wayward," "utterly unfounded," "baseless," and "pure hokum"; and has implied a similarity between me and "fundamentalists in another country [who] have kept Salman Rushdie under a death sentence" (Ring, 2000, p. 241).

On another level, these "wars" do not directly involve religion, but consist of honest disagreements over research methodology and interpretation irrespective of the religious beliefs of the persons involved. For my part, I have openly questioned the reliability of Rawlings' work and have argued against his claim that the NDE is a literal trip to the afterlife (Sabom, 1996, 1998). I have rebutted Abanes' conclusion that NDEs "take place entirely in the mind" and are "nothing more than biologically based hallucinations built from sensory data and preexisting memories/thoughts/dreams" (Abanes, 1996, p. 108). I have refuted Susan Blackmore's materialistic interpretations of the NDE and argued that it is a spiritual experience (Sabom, 1998, pp. 183-184 and 198-204). I have maintained that Ring transgressed his own personal strictures by proposing an NDE-based religion with "prophets preaching a religion of universal brotherhood" (Sabom, 1998, pp. 131-141; Sabom, 2000). And I have confronted Moody's reversal of his previous interdiction against "allowing the entrance of spiritualism, with all its bizarre trappings, into medicine" (Sabom, 1998, pp. 144-145).

Ellwood now enters the fray seeking "to deepen sympathetic understanding of the issues" by critiquing my work. She avoids using ad hominem attacks and the standard orthodox Christian-nonChristian discourse, challenging instead the meaning of the word "Christian" itself. She begins her commentary on Light \& Death with a revealing misstatement certain to usher in misunderstanding: "Sabom's recent book criticized various developments in NDE studies of the last fifteen years, particularly the work of Kenneth Ring, from a Christian viewpoint ..." (italics added). 
My criticism of Ring's work was not from a Christian viewpoint, but from the viewpoint of his own editorial in which he inveighed against the use of NDE research for hortatory purposes (Ring, 1980). As I noted in a previous article,

[m]y concern here is not with the type of belief system he advocated, but with his methodology.... While it is true that in Chapter 11 I use the Bible to evaluate the NDE, the analysis of Ken's work in Chapter 6 is not linked to my Biblical evaluation of the NDE in that last chapter of my book. (Sabom, 2000, p. 246)

Ellwood's misrepresentation highlights an all-too-frequent mistake (or bias) whereby the summary interpretation of data in my last chapter is categorically construed as coloring everything else in my book. My discussion of Moody's work, furthermore, begins not with a Christian critique but, as with Ring, with his own published warnings.

\section{The Research of Raymond Moody: "A Grand Diversion"}

In Light \& Death, my evaluation of Moody's work began with his own strongly-worded statement:

A final note of warning: in my mind, the interesting results of these studies of medical patients who have nearly died should not be used as an excuse for allowing the entrance of spiritualism, with all its bizarre trappings, into medicine. Presumably for as long as there have been human beings, shamans have pretended to put their clients into touch with the spirits of the departed. The history of fraud and fakery associated with such dealings is too well known (and too ancient!) to bear repeating. The validity (if any) of such performances is best assessed by professional illusionists, not by medical doctors.

Near-death experiences, by contrast, happen not in darkened rooms in circumstances contrived by witch doctors, but in the bright light of modern emergency and operating rooms, presided over by physicians. (Moody, 1980, p. 265, italics added)

Since 1980, medical doctor Raymond Moody has failed to heed his own warning as he now guides "subjects" through "grief weekends focusing on the therapeutic value of reuniting with departed loved ones" (McNicholas, 1995). He uses "mirror gazing" to "diagnose a variety of problems, including specific anxieties, depression, and marriage problems" (Moody and Perry, 1993, p. 157).

Ellwood takes me to task for using "such abusive terms as 'dog-andpony show,' 'witch doctor,' 'spiritualism with all its bizarre trappings' (a phase borrowed from an earlier statement of Moody's), and 'a cage from which many will, unfortunately, not return." Obviously, the term 
"witch doctor," like "spiritualism with all its bizarre trappings," was borrowed from Moody's own words of warning above.

The phrase "dog-and-pony show" refers to medium George Anderson's errant attempts in front of an Atlanta audience to "randomly select individuals for live readings as directed by the Other Side." During this "Grief Support Seminar," his continued efforts to "link up" with the "Other Side" despite repeated and observable failures smacked of hollow entertainment. But this should come as no surprise. Anderson himself likens his role as "bereavement counselor" not to scientific method, but to "playing ball": "Every time a ballplayer steps up to the plate, he doesn't hit a home run, but that doesn't mean he can't play ball" (Anderson, quoted in Reed, 1999, p. 120).

Even more pointedly, Moody has taken the entertainment/game approach to his psychomanteum-centered therapeutics. On the one hand, he soberly recognized

[t] he wish for reunion with loved ones lost to death is among the most poignant and insistent of human desires. The desire taunts and saddens us with a litany of what ifs and if onlys, and mournful pleas of only five minutes more. (Moody and Perry, 1993, p. ix)

On the other hand, he jocularly maintained that

[i]f all of this seems more like play than science, then I have accomplished my goal. (Moody and Perry, 1993, p. 181).

[T] he time has come to look at things a new way, to stop taking everything so seriously, and, in fact, to consider the possibility that the very reason that ordinary people find the subject of the paranormal so continually fascinating is precisely because they do not take it seriously, but, rather, find the whole topic eminently entertaining-a grand diversion. (Moody, 1999, p. 164)

Thus, characterizing Anderson's performance as a "dog-and-pony show" not only connotes the entertainment feature that Moody may well intend, but captures the helplessness of vulnerable people on parade without the conscious complicity that such participatory entertainment should require.

Ellwood surprisingly does not address Moody's 180 degree turnabout from a psychiatrist who soberly condemned the "entrance of spiritualism with all its bizarre trappings, into medicine" to one who regularly uses "evocation of the dead" for "grief counseling." Instead, she focuses on my assessment (which, interestingly enough, aligns closely with Moody's earlier appraisal) of "psychic experiences, particularly attempts to communicate with the deceased" as being "very negative." 
She claims that my negative "conclusions about these psychic happenings [are] out of keeping with their described character" and with my "research data." Here Ellwood is confusing my negative assessment of sought-after psychic experiences (the type used by Moody and others) with my neutral assessment of spontaneous psychic experiences (the type researched in my Atlanta Study). In Light \& Death, I drew this important distinction in the following way:

The comments made by two conservative Christians about their outof-body experiences are interesting. Both had put a negative spiritual spin on these encounters when they intentionally induced them, and they felt as if their efforts in this direction led them into Satan's path. When similar experiences occurred spontaneously, however, as during an NDE, no such condemnation was forthcoming. (Sabom, 1998, p. 162)

Conservative theologians such as R. C. Sproul, Professor of Systematic Theology at Reformed Theological Seminary, believe as I do that spontaneous experiences, such as NDEs, are worthy of careful study:

It shouldn't shock the Christian when people undergoing clinical death and being revived come back with certain recollections. I've tried to keep an open mind, and I hope that this interesting phenomenon will get the benefit of further research, analysis, and evaluation. (Sproul, 1996, p. 300)

\section{But sought-after experiences are}

a radical offense to God. We're simply not permitted to be involved in seances, in spiritualism, or in the use of mediums. That is anathema to God, and in fact, people who do that are in the final chapter of the New Testament as those who are excluded from the kingdom of God [Rev. 22:14]. The warnings are severe and weighty about being involved in these kinds of activities. (Sproul, 1996, p. 298)

The Bible likewise speaks of spontaneous "supernatural manifestations" that need testing by "the word of God," as opposed to sought-after "occult involvement" such as "spiritism, mediumism, necromancy, and magic," which is flat-out condemned:

God teaches that spiritual warfare is a reality (Eph. 6:10-18; 2 Cor. $2: 11 ; 1$ Pet. 5:8) and that supernatural manifestations are not to be accepted uncritically but to be tested by the Word of God ( 1 John 4:1; Rev. 2:2; Acts 17:10-12; Deut. 18:20-22; Matt. 24:24, etc.)... In many instances, Scripture explicitly cites Satan or his demons as the reality behind occult involvement, idolatry, and false religion (Deut. 32:16, 17; 1 Cor. 10:19-21; Psalm 106:35-40; 1 Tim. 4:1; Thess. 2:9, 10; Acts 16:16-19, etc.). This is one reason why God considers occult activity in virtually all its forms as an abomination (Deut. 18:9-12)-because 
it links those for whom Christ died to evil spirits who are His enemies. Thus, occult involvement will eventually lead to judgment for those who refuse to forsake it (Rev. 22:15; 2 Chron. 33:6). Scripture condemns by name spiritism, mediumism and necromancy (Deut. 18:9-12; Hosea 4:12; Ex. 22:18; Isaiah 44:25; 29:8, 9; Ezekiel 21:21; e.g., astrology, Deut. 17:2-5; 2 Kings 17:15-17; Isaiah 47:9-14); and magic (Acts $13: 8 ; 19: 16-19$; Isaiah 47:9, 12). In their numerous forms these basic categories (magic, spiritism, divination, and sorcery) cover almost the entire gamut of occult activity. (Ankerberg and Weldon, 1993, p. 264)

Thus, from a Biblical standpoint, spontaneous psychic experiencesincluding NDEs, visions, out-of-body experiences, and precognitionshould be carefully evaluated, whereas the sought-after variety should be flatly avoided. Brooks Alexander, senior researcher for Spiritual Counterfeits Project in Berkeley, California, explained why:

The fact is that no one knows how demonic beings operate in relation to psychic phenomena. Therefore it is impossible to say that " $\mathrm{X}$ " amount of psychic involvement will result in demonic contact. We do not know where the line is drawn between dabbling and demonism, or between curiosity and commitment, nor do we know how and when that line is crossed. It may be that the question of "how much" has less to do with it than we think. I would suggest that the neural and mental pattern set up by psychic involvement provides an interface with other forms of consciousness, which are extradimensional and demonic in nature. If that is the case, psychic dabbling is a little like entering the cage of a man-eating tiger. You may or may not be eaten, depending in part on how hungry the tiger is. The significant point is that once you enter the cage, the initiative passes to the tiger. (Alexander, quoted in Sabom, 1998, p. 163)

In her commentary, Ellwood alleges that my negative assessment of psychic and occult involvement is "completely theological," dubs my use of the "cage" and "tiger" metaphor "abusive," and attributes such thinking to "Sabom's intention to defend his [religious] subworld." Similarly, Moody passed off notions of "Satan" and "demons" to aberrant beliefs of "infernally-oriented, Satanically-focused, funda-Christian[s]" (Moody, 1997 , p. iv). And Ring, in his commentary on Light \& Death, impugned my

warnings about dabbling with psychic matters, testing the spirits, Satanic deceptions with demons posing as beings of light or even masquerading as the Christ... [by attributing them to] the whole familiar litany of conservative Christian exhortations against anything that might deviate from their understanding of Biblical truth or threaten to undermine it. (Ring, 2000, p. 241) 
Have I been blinded by the beliefs of my own "religious subworld"? Let's take a look.

\section{Entering the Psychic Cage}

Robert Monroe was one of the world's foremost pioneers in the psychic and occult. In 1958, Monroe began having out-of-body experiences, traveling "to locales far removed from the physical and spiritual realities of his life ... a place unbounded by time or death" (Monroe, 1973, back cover). Fascinated by these experiences, he established The Monroe Institute in 1974 to develop and then teach techniques to induce these experiences. Monroe described the psychic realm as one with a

completely different set of rules, another world of entirely different possibilities, populated by beings who seem to know all of them. You have no rule book, no road map, no book of etiquette, no applicable courses in physics and chemistry, no incontrovertible authority you can turn to for advice and answers. (Monroe, 1973, p. 206)

Whitley Strieber is a best-selling author and researcher of "alien abductions." Like Monroe, he has been extensively involved in the world of the psychic and occult. When we enter the psychic world, Strieber wrote,

[w]e become like an ant trapped upon a hanging Christmas ornament: We have crossed our own path so many times that we cannot deny the reality of the trap. But we cannot see our way out. So we stop, we reach into the air, we feel blindly. (Strieber, quoted in Ring, 1992, p. 19)

During his psychic adventures, Monroe encountered malevolent "beings":

I started out [of my body] carefully-and felt something climb on my back!...

It seemed to be trying to get back on me, and I had to hold it away. ... I was getting a little panicky. I was over my head again! I thought of lighting matches and trying to burn him up, to do something, anything. There seemed no way to prevent him from climbing back on me until the moment I re-entered the physical....

Then, as I was trying to hold off the first, a second climbed on my back! Holding off the first with one hand, I reached back and yanked the second off me, and floated over into the center of the office, holding one in each hand, screaming for help. I got a good look at each, and as I looked, each turned into a good facsimile of one of my two daughters!... I seemed to know immediately that this was a deliberate camouflage on their parts to create emotional confusion in me and 
call upon my love for my daughters to prevent my doing anything more to them....

By this time, I was sobbing for help....

Then I saw someone else coming up out of the corner of my eye. I first thought it was another one, but this was very definitely a man...

I was still sobbing when he slowly approached us; I was down on my knees, arms outstretched, holding off the two little beings .... He wore a dark robe down to his ankles.... When he came close, I stopped my struggling, and sank to the floor pleading for help. Still with no recognition of me, he picked up each of the little beings....

Sobbing my thanks, I moved over to the couch, slipped into the physical, still feeling the vibrations, and sat up physical and looked around. The room was empty.

After a twenty-four hour contemplation of the event,.... I still don't know what they [the beings] are.... Who does the man in the robe represent? (Monroe, 1973, pp. 138-140)

Strieber similarly encountered a "depressing array of demonic or coldly indifferent entities" in his paranormal excursions:

Having had the experience many times, I can attest to its remarkable combination of subtlety and extraordinary impact. To come to terms with it, I went through five years of sheer hell, and still find it difficult to believe that the experience was not caused by an intelligence external to myself. Indeed, all of my internal references to it remain essentially other, despite the insistence of my intellect that this is almost certainly not the case....

I have been able to observe details of its intelligence that so strongly point to its human origins that I can only say that, if aliens are here, they have learned to mimic the inner mind of man....

[T] hey have done an expert job of confusing the issue. Perhaps their final disguise will be our own conviction that they come from within us. (Strieber, quoted in Ring, 1992, pp. 16-19)

The goal does not seem to be the sort of clear and open exchange that we might expect. Whatever may be surfacing, it wants far more than that. It seems to me that it seeks the very depth of the soul; it seeks communion. (Strieber, 1987, p. 5)

These chilling accounts by Monroe and Strieber closely resemble the metaphor of "entering the cage of a man-eating tiger." This "cage" is a spiritual realm in which the rules of our physical world do not apply. It is populated by "beings" or "demonic entities" who know the rules and use them to accomplish "an expert job of confusing." They employ "intelligence" and "disguise" to "mimic the inner mind of man." They utilize "deliberate camouflage on their parts to create emotional confusion." Their ultimate goal is to seek "communion" with "the very depth of the soul." 
Swedish scientist, philosopher, and theologian Emanuel Swedenborg, considered by many to be one of the greatest and most learned men of his country, summed it up this way:

When spirits begin to speak with a man, he ought to beware that he believes nothing whatever from them; for they say almost anything. Things are fabricated by them, and they lie.... They would tell so many lies and indeed with solemn affirmation that a man would be astonished.... If a man listens and believes, they press on and deceive and seduce in [many] ways... . Let men beware therefore. (Swedenborg, quoted in Ankerberg and Weldon, 1993, p. 129)

Compare now these observations by Monroe, Strieber, and Swedenborg to Biblical descriptions of Satan and his demons. Satan is the leader (Matt. 8:28; 9:34; 12:26; Luke 11:18-19) and is called "the father of lies" (John 8:44). His demons "speak lies of hypocrisy" (1 Tim. 4:1-2). These evil spirits use great talents, power, and knowledge to spread confusion and false teaching (Matt. 8:29; Mark 1:24). They lay snares for their victims (1 Tim. 3:7) and seek to devour them as a roaring lion (1 Pet. 5:8). As "familiar spirits," they can transform themselves into apparitions of readily identifiable people. (Recall the likeness of one of Monroe's daughters appearing on the face of evil spirits during an out-of-body experience.) At times, they disguise themselves as angels of light to evoke awe and worship (2 Cor. 11:4). Their ultimate goal is the destruction of the soul.

These Biblical descriptions of evil spirits are substantiated nearly word for word by well-known nonChristian researchers with extensive knowledge of the psychic and occult. To dismiss casually the very real possibility, if not probability, that "familiar spirits" appearing during an NDE may in fact be demonic deceptions is to ignore the evidence blindly. Indeed, these Biblical warnings are further authenticated by psychiatric and psychological reports.

\section{Aftermath of the Psychic and Occult}

Psychoses and schizophrenic-like symptoms have been reported following occult involvement. In the medical literature,

[p]sychiatric diseases resulting from occult practices or spiritualist influences have long been known. Henneberg in 1919 first described independent forms conceived as having a psychological genesis as 'mediumistic psychoses'... . In classifying 'mediumistic psychoses,' it appears appropriate to give first consideration to atypical schizophrenic disorder." (Vollmoeller, 1994) 
Psychiatrists from the University of Zurich studied mediumistic psychoses in persons actively engaged in "paranormal experiences." They found that "dissociation of subpersonalities (subselves)" along with "the splitting of non-ego parts of the psyche leads to a manifestation of schizophrenic symptoms" (Scharfetter, 1998).

German theologian Kurt Koch has counseled more than 11,000 persons in his $\mathbf{4 5}$ years of dealing with problems arising from occult practices. He wrote:

It is known particularly in the field of psychiatry that prolonged activity with mediumistic forces produces symptoms of schizophrenia. This has been termed mediumistic psychosis. Psychology too has drawn certain conclusions on the matter, and Professor Bender, a psychologist of the University of Freiburg in his booklet entitled "ParapsychologyIts Results and Problems," has warned people in these words: "Thousands of people base their hopes on the deceptive statements of spiritistic practitioners and subsequently become dependent upon the advice they receive from the 'other side.' I have quite a number of patients who have suffered serious psychic disturbances through the misuse of such practices. Their personalities have been split and they have been utterly confused by the spirits on which they have called. (Koch, quoted in Ankerberg and Weldon, 1993, p. 163)

John Warwick Montgomery is Professor of Law and Humanities at the University of Luton, England, holds eight earned degrees, and has authored more than 100 scholarly journal articles and some 40 books. He has observed

a definite correlation between negative occult activity and madness. European psychiatrist L. Szondi has shown a high correlation between involvement in spiritualism and occultism (and the related theosophical blind alleys) on the one hand, and schizophrenia on the other. (Montgomery, quoted in Ankerberg and Weldon, 1993, p. 164)

Clinical psychologist Eleanor Criswell commented as well that

[t]he experiences dealt with in a psychic counseling setting have an exceptionally broad range.... Frequently such individuals have been hospitalized in mental institutions and have sometimes undergone electro-convulsive therapy and other somatic treatments in order to stop the psychic process. (Criswell, quoted in Ankerberg and Weldon, 1993, p. 141)

Psychic researcher and author Scott Rogo warned that the "types of negative reactions people initially have to their psychic experiences may lead to permanent psychological damage if not immediately treated" (Rogo, quoted in Ankerberg and Weldon, 1993, p. 178). 
Suicide has been linked to psychic involvement. Paul Beard, author and past president of the College for Psychic Studies in London,

notes the presence of certain spirits who attempt to "break down the personality [they are] obsessing in order to reduce it to neurosis or even possible suicide." This pattern of spirit obsession "is virtually universal and has been observed by the victims of such influences, as well as by psychic researchers and spiritualists in many parts of the world." (Beard, quoted in Ankerberg and Weldon, 1993, p. 133)

German physicians noted the particularly uncommon occurrence of double suicide among homosexuals and then presented the case of

a dual suicide by hanging among two 20 -year-old lesbian women. Due to abnormal psychic development and mutual induced reaction the thought of dying together and being reborn jointly in one person (a contemporary actor) arose. These ideas were influenced by spiritism and metempsychosis.... [and were] well documented.... (Grellner and Krull, 1996)

Spiritual counselor and author Morton Kelsey reported that "Two researchers working with the problem of suicide in Los Angeles were amazed at how often, in the course of their interviews, people who showed suicidal tendencies referred to contact with the dead" (Kelsey, quoted in Ankerberg and Weldon, 1993, p. 168). And Carl Wickland, a physician and psychology researcher with more than 30 years experience communicating with the spirit world, found that "a great number of unaccountable suicides are due to the obsessing or possessing influence of... spirits. Some of these spirits are actuated by a desire to torment their victims" (Wickland, quoted in Ankerberg and Weldon, 1993, p. 27).

In addition to the damaging psychiatric and psychological aftermath of psychic and occult involvement, the danger of human deception is also very real.

\section{"New Age Thanatothespians"}

In March, 1997, Moody sent me a copy of his book The Last Laugh published by William Moore Consulting in Atlanta, Georgia (Moody, 1997). This book was later republished under the same name by Hampton Roads Publishers (Moody, 1999). In the William Moore edition, Moody offered an insider's glimpse of NDErs masquerading as "New Age thanatothespians." This material, largely deleted in the Hampton Roads edition, focused on Dannion Brinkley, arguably the person most recognized 
for NDE-associated psychic abilities. These words of Moody's were not written from a "religious subworldview":

The complex, fascinative, and amusive dynamics of near-death experiences set the stage for their exploitation in the entertainment media. So it was predictable that popular demand for tidings from the Near Beyond would give rise to a new breed of performers I dub the NDEntertainers....

Two NDEntertainers in particular have scored big hits-Betty Eadie, author of Embraced by the Light, and Dannion Brinkley, who told his story to journalist Paul Perry, who artfully crafted it into Saved by the Light....

I met Dannion in 1976, several months after he barely survived being struck by lightning. [During his NDE, he was shown a series of encapsulated visions which, he was led to believe, were] visual representations of events that were to take place in the future.... [T] he majority of Dannion's foreseeings were the typical soothsayer-fare-looming famine, war, economic depression, societal disarray....

[Sometimes] he issued predictions that seemed totally off the wall at the time, only to be fulfilled later with chilling precision.

Then I must go on immediately to add that I have seen and heard him pronounce many other prophecies, detailing even the exact day, month, or year of their forthcoming, and all in the same preemptory voice and manner of all-confident authority, that never did materialize as he said they would....

Nor is Dannion ever bothered for a minute by any of his misforeseeings, for when prophecies fail, fresh ones soon are heard tripping from his tongue to replace the worn out ones....

He holds listeners spellbound, on the edge of their seats, but as long as I have known him, I have never been able to track his train of thought. He speaks in a rapid-fire double-talk that makes it impossible for anyone else to get a word in edgewise. His inimitable manner of oration is a word-blizzard of rodomontade; according to him, he has a long list of distinctions and innovations to his credit. Over the years he has told me this: he went to film school with Steven Spielberg or George Lucas; he worked closely with Jacques Cousteau; he invented and marketed an electronic device that keeps barnacles from growing on the sides of ships and enables deaf children to hear; he owns a highsecurity electronics firm in Washington, D.C., that debugs Pentagon offices; he once had his own clown character and hosted a popular kid's television show; he has organized a country-wide chain of stress relief centers that have been just about to open any day now for the past seven years, etc., etc., etc. Yet I never have seen any real evidence that any of these claims are true.

To make all of this even better, Dannion interweaves his dazzledrama of overpowering individuality into an incredible, ongoing spytale of cloak-and-dagger intrigue and swashbuckling military accomplishment. At various times, he has told me that he works for the CIA, for the DIA, and for the Chairman of the Joint Chiefs of Staff, and that 
he is a colonel in the Marine Corps. He once told me that he spent his nineteenth birthday in a foxhole in Vietnam, and that he killed nineteen enemy soldiers that day....

According to a newspaper report, the Defense Department claims Dannion never went to Vietnam at all, but spent his brief military career as a PFC driving a truck in Atlanta.... (Moody, 1997, pp. 177-184)

Is Brinkley's deceptive "rapid-fire double-talk" and "word-blizzard of rodomontade" unique within the world of the psychic and occult? Martin Ebon, a former secretary of the Parapsychology Foundation, managing editor of the International Journal of Parapsychology, editor of Spiritual Frontiers, and an author of several books on parapsychology, has found "much darkness and greed" in the psychic world and likens participation to a game of Russian roulette: "A game in which the element of danger is ever present and must be acknowledged" (Ebon, quoted in Ankerberg and Weldon, 1993, p. 131). Raymond Van Over, another former editor of the International Journal of Parapsychology and author of books on the occult, has likewise warned that the psychic world "is a world where few stabilizing or discriminating personalities function as a counter example. It provides fertile ground upon which neurotic and dangerously unstable personalities can flourish unquestioned" (Van Over, quoted in Ankerberg and Weldon, 1993, p. 132).

Ellwood points to "a clear conflict between warnings to avoid them [i.e., occult practices] stemming from a religious subworldview, and the need for scientists, historians, philosophers and others to be free to investigate them in order to seek the truth and expand the human experience..." (italics added). My intent, however, is not to infringe on the freedom of others to investigate psychic activities and the occult, but to call attention to the dangers of such investigation. As we have seen, these warnings come not only from persons sharing my "religious subworldview," but from a heterogeneous group of religious and nonreligious researchers, psychiatrists, psychologists, and counselors as well.

\section{Biblical Accuracy and the Words of Jesus}

Ellwood criticizes my use of the Bible as "our only reliable yardstick." She bases this critique on what she has termed "modern Biblical scholarship" conducted by "mainline scholars" who have "taken as starting-point that the Bible is not an infallible record but a collection of thoroughly human writings, a cultural product." According to this view, "the accounts of Jesus' life in the four Gospels are not 
historically reliable.... Some of the fragments probably reflect accurately what Jesus said and did ... others were altered ... while still others are fictional." Although her stated intent is to "deepen sympathetic understanding of the issues," her one-sided analysis dismisses out-ofhand the views of "traditionalist Biblical scholars" and researchers who have carefully refuted claims that the Bible is unreliable (Ankerberg and Weldon, 1997; Blomberg, 1987; Craig, 1981, 1993; Habermas, 1988, 1996; Metzger, 1992; Sheler, 1999; Strobel, 1998; Wilkins and Moreland, 1995).

Furthermore, it is curious that Ellwood endorses, on the one hand, the "valuable insights" of "mainline scholars" when they exposit the inaccuracy and unreliability of the Bible, while on the other hand she balks at their conclusion that "Biblical accounts of paranormal events (including return from death) are exaggerated or fictional" -an error that she attributes to "the modern worldview that reigns in much of the academy [which] dictates that paranormal events cannot happen." Her basis for discerning "valuable insights" from error seems arbitrary, however, leaving one to wonder whether the "modern worldview that reigns in the academy" has tainted all, and not just some, of these controversial teachings. Could not these "mainline scholars" have erred in their conclusions regarding both paranormal events and reliability of the Bible?

In Light \& Death, I used a "traditionalist" view of the Bible as articulated by Darrell Bock, Professor of New Testament studies at Dallas Theological Seminary:

Some treat the words of Jesus like a "memorex" cassette tape. The red letters of the Gospels are the exact words Jesus spoke... not a summary or the gist of that... The other end of the interpretative spectrum is [what I have loosely termed "jive" and is] represented by the Jesus Seminar. This approach emphasizes the loose oral roots behind the communication of Jesus' teaching and the Evangelists' need to adapt that teaching for their preaching. According to those who hold this position, the Gospel writers had and took the opportunity to create sayings.... The Jesus Seminar only manages to rate 18 percent of the sayings of Jesus as being directly from him (in red letters) or something close to what he said (in pink letters)... A third ["live"] approach-rooted in a careful understanding of how historical events and sayings were remembered and recorded in the first century and drawing on careful attention to the biblical texts themselves-leads us to recognize both the writers' accuracy and the nature of the differences in their accounts.... Such variations, reported by authors who know the tradition's wording, reveal their intent to summarize and explain, not merely to quote... We clearly hear Jesus, but we must 
be aware that there is summary and emphasis in the complementary portraits that each Evangelist gives to the founder of the faith. Jesus' teaching is both present in the Gospels and reflected on in light of the significance his teaching came to possess. ... [T] his is what the Gospel writers intended to do: nothing more ("memorex") and nothing less ("jive")... [S] uch reporting is both common and capable of being fully trusted. (Bock, quoted in Wilkins and Moreland, 1995, pp. 74-77)

Using Bock's "live” interpretative method, let us consider Ellwood's use of the words of Jesus. First, in asking "How central is exclusivism to Christianity?" she contrasts the following verses: "In the Gospels Jesus was quoted as saying 'He that is not with me is against me,' (Matthew 12:30) but $\mathrm{He}$ is also quoted as saying the opposite: 'He that is not against us is for us' (Luke 9:50)." The contradiction implied here is resolved when we discover in Matthew 12:30,

the Saviour is speaking of the conflict with the Evil One. And in that conflict there is no room for neutrality. But in verse [Luke 9:] 50 it is a question of someone who believed in Jesus to such an extent that he cast out demons in His name and who revealed such an humble attitude that he allowed the disciples to forbid him to continue to work.... So the Saviour teaches them [i.e., the disciples] to be more magnanimous and more tolerant. (Geldenhuys, 1988, p. 289)

In this latter situation, however, Jesus

does not enjoin us to give a loose rein to rash men, and to be silent while they intermeddle with this and the other matter, according to their own fancy, and disturb the whole order of the Church: for such licentiousness, so far as our calling allows, must be restrained. $\mathrm{He}$ only affirms that they act improperly, who unseasonably prevent the kingdom of God from being advanced by any means whatever. And yet he does not acknowledge as his disciples, or reckon as belonging to his flock, those who hold an intermediate place between enemies and friend, but means that, so far as they do no harm they are useful and profitable: for it is a proverbial saying which reminds us that we ought not to raise a quarrel till we are constrained. (Calvin, quoted in Pringle, 1996, p. 373)

Is Christianity then exclusive? The answer is "No," if by "exclusive" we mean that within the Christian religion, there is only one proper way to worship Jesus Christ. Different Christian churches and denominations embrace diverse approaches. Christianity is exclusive, however, in its assertion that only Jesus Christ is Lord, and that only through Christ is salvation received. (I will return to this point below.)

Second, Ellwood questions my conclusion that the "Christ" that Eadie and George Ritchie encountered in their NDEs was not the Biblical 
Jesus. Recall here Strieber's stern warning that the spiritual realm is populated by "demonic entities" who accomplish "an expert job of confusing," and Swedenborg's caution that we should believe "nothing from them; for they say almost anything." Given the possibility that the messages received by Eadie and Ritchie may be false and misleading, I turned to the Bible to evaluate these NDE "Christs." I based my reasoning on Matthew 7:16: "By their fruit you will recognize them." Ellwood suggests, however, that my conclusion is in error because I offered no "evidence in the form of bad fruit" in the lives of Ritchie and Eadie.

In Matthew 7:15, the immediately preceding verse, Jesus warned: "Beware of false prophets, who come to you in sheep's clothing, but inwardly are ravening wolves." It was their "fruit" which was "bad," and their "fruit" was false doctrine. I enumerated several examples of just such false doctrine espoused by Eadie and Ritchie - doctrine clearly in opposition to Biblical teaching (Sabom, 1998, pp. 216-217), which is consistent with Strieber's and Swedenborg's warnings above. Moody has likewise voiced strong concern over Eadie's "fruit" in particular:

I once saw Betty breeze through a stack of written queries submitted by audience members. She read each question aloud- "Are people who commit suicide punished for it in the afterlife?" "Do dogs make it to the beyond?" "Is there a Hell?" Then, she confidently dashed off a definite "yes" or "no" answer to each....

In my experience, [her] behavior diverges sharply from what is heard from most NDExperients during private, one-on-one interviews. In that kind of setting, average NDExperiencers are reticent to make grand pronouncements. They are willing to own up to their own inner assurance of a life hereafter, to be sure. It seems that, for most people, having a transcendental near-death experience does put to rest the vexing, innermost personal issues of survival of bodily death. But beyond that, most are acutely aware of the futility of trying to provide any ultimate solutions to humankind's cosmic concerns about a life after death. (Moody, 1997, p. 187)

Third, Ellwood asks "Which are we to use in judging the content of NDEs and their effects? Should we choose the Jesus of the Sermon on the Plain who said 'Love your enemies, do good to those who hate you' (Luke 6:27) and later asked forgiveness for his crucifiers (Luke 23:34)? Or should we judge by the incipiently antisemitic Jesus who accused his opponents, 'the Jews,' of being children of the devil (John 8:44)?"

In these verses, four actions are addressed: showing love, doing good, asking forgiveness, and speaking truth. The basis for love, goodness, and forgiveness is truth; and the basis for truth is what is true, not necessarily what is appealing. Jesus, the Jew, rightly identified Satan 
as the source of the nonbelieving Jews' desire to murder him. Speaking this truth was, in essence, a loving act, because the identification of evil is the first step in changing it. Once this evil had been identified, Jesus asked, while dying on the cross, for forgiveness for those who had perpetrated it: "Father, forgive them, for they know not what they are doing" (Luke 23:34). These three verses are thus found to complement one another.

Fourth, Ellwood asks: "Are we to judge by the Jesus who said 'Let the little children come to me ... for to such belongs the Kingdom of God' (Luke 18:16), or the Resurrected One who threatened to kill the children of the prophetess 'Jezebel' because of the actions of their mother (Revelations 2:20-23)?”

In the Luke passage, the word "children" refers to infants and youngsters (Calvin, quoted in Pringle, 1996, p. 390). In Revelation 2, however,

Jezebel's 'children' are not the literal offspring of her adulteries ... but those who have so unreservedly embraced the antinomian doctrines of their spiritual mother that they are best described as younger members of her family. No particular distinction should be drawn between the children of Jezebel and 'them that commit adultery with her.' (vs. 22) (Mounce, 1977, p. 104, italics added)

Finally, Ellwood notes that "in John 14:12 Jesus was presented as saying 'He that believeth in me, the works that I do shall he do also; and greater works than these shall he do..." Since Jesus raised people from the dead, she contends, then we should likewise be able to perform "callbacks from death.” In Light \& Death, I argued the opposite: the NDE is a near-death, not an after-death experience. Doctors resuscitate, not resurrect, their patients. Biblically, I used both Old and New Testament verses to support this view: 2 Samuel 14:14 (at death, we are "like water spilled on the ground, which cannot be recovered, so we must die"); Hebrews 9:27 ("man is destined to die once"); and Luke 16:26-31 (the parable of Lazarus and the rich man, where the rich man was prevented from returning from the dead to warn his family of the reality of hell). Ellwood correctly notes that Jesus raised persons from the dead (Mark 5:21-42; Luke 7:11-15; John 11: 1-44). However,

[w]hat Jesus means [when $\mathrm{He}$ instructed that we shall do "greater works than these,"] we may see in the narratives of the Acts. There are a few miracles of healing, but the emphasis is on the mighty works of conversion. "Greater works" mean more conversions. There is no greater work possible than the conversion of a soul. (see fn. 31) On the day of Pentecost alone more believers were added to the little band of believers than throughout Christ's entire earthly life. There we see a 
literal fulfillment of "greater works than these shall he do." (Morris, 1971, p. 646)

Thus, when properly understood, the words of Jesus that Ellwood calls into question do not contradict one another, and do not support her claim that the "Biblical Jesus is in fact a number of interpretations, some mutually inconsistent."

\section{Research Methodology in The Atlanta Study}

Ellwood points to "bias" in my Atlanta Study protocol by referring first to a previous statement of mine on this subject:

[W] all need to do research in a way that data can be used by anyone for whatever reason they want to use it. There's no such thing absolutely clean data, but I do think that we need to strive much harder to do research into the NDE which is not encumbered by our own presuppositions and preconceptions. Once we can do that we can talk on a level of "Well, what does your data show; what does my data show? (Sabom, quoted in Abanes, 1994, p. 189, italics added)

In collecting data for The Atlanta Study, I utilized a formal, structured format (Sabom, 1998, pp. 33-34), and "to add objectivity, The Atlanta Study interviews were conducted in a neutral setting, and the religious views of the researcher were not discussed prior to the interview" (Sabom, 1998, pp. 139-140). Despite these precautions, I do not maintain that I collected "absolutely clean data," since subtle interactions and body language between interviewer and interviewee can and do influence responses. When Ellwood speaks of bias, however, she has something different in mind:

An example [of Sabom's bias] is the way in which his own religious convictions influenced his categorization of the religion of his subjects. He classed as 'Christian' only those who answered 'true' to the statement 'Jesus Christ is the Son of God and thus supreme over all other great religious leaders,' a statement that Jesus is dominant over others.... ... This view, which may have slanted his statistics, precludes classing as Christians those persons who have a devout and life-permeating commitment to Christ yet believe that other religions lead as well to God.... But it is unfair to claim, without evidence, that all Christians who disagree with one's own Christian theology lack a deep and realized commitment to follow Jesus.

Ellwood is here confusing my use of the word "data" with "categorization of data." In Light \& Death, I introduced my categorization scheme with the disclaimer that "Bible scholars don't exactly agree on precisely 
what is meant to be a Christian. But to analyze the results of The Atlanta Study, I had to set up a few boundaries" (Sabom, 1998, p. 108). I have since emphasized that "[t]hese categories were set up for research purposes only, not as theological commentary. Since the data (individual responses to each questionnaire) were acquired and maintained independent of these categories, reanalysis of this data using differently-defined subgroups could, if necessary, be easily undertaken" (Sabom, 2000, p. 254). Setting up clearly-defined "boundaries" within which to group data does not bias the data itself. Charles Tart, a respected nonChristian NDE researcher, recognized this important distinction:

What I like about your book is that your Christian perspective is right up front. Since it's up front, I can call it a perspective rather than a bias. I can agree or disagree with particular statements that you clearly make from your perspective, but I'm not worrying that you have "biases," i.e., that your hidden perspective has led you to seriously distort the data and so mislead others about the data. (C. Tart, personal communication, February 20, 1999)

But the question remains: Was I "unfair to claim, without evidence" that "those persons who have a devout and life-permeating commitment to Christ yet believe that other religions lead as well to God" are not true Christians? Jesus declared himself to be the Son of God (Sabom, 1998, pp. 194-196). Furthermore, He clearly stated that "He who does not honor the Son does not honor the Father who sent Him" (John 5:23); "Truly, truly, I say to you, he who does not enter by the door into the fold of the sheep, but climbs up some other way, he is a thief and a robber... I am the door; if anyone enters through Me, he shall be saved" (John 10:1, 9 ); “[H]e who rejects Me rejects the One who sent Me" (Luke 10:16); and "I am the way, and the truth, and the life; no one comes to the Father, but

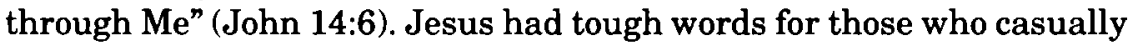
used his name:

'Not everyone who says to Me, 'Lord, Lord,' will enter the kingdom of heaven; but he who does the will of My Father who is in heaven. Many will say to Me on that day, 'Lord, Lord, did we not prophesy in Your name, and in Your name cast out demons, and in Your name perform many miracles?' And then I will declare to them, 'I never knew you; Depart from Me, you who practice lawlessness.' (Matthew 7: 21-23)

Furthermore, Jesus warned that

if anyone says to you, "Behold, here is the 'Christ,'" or "There $\mathrm{He}$ is," do not believe him. For false Christs and false prophets will arise and 
will show great signs and wonders, so as to mislead even the elect. (Matthew 24:23-24)

\section{In Light \& Death, I recognized that}

[m]ost researchers tend to lump all self-proclaimed Christians together. The problem with this approach is that some who claim to be Christian or indicate "Christian" on a survey actually believe the traditional doctrine that Jesus was the divine son of God, while others mean they are Christian in a more general or cultural sense but do not hold to such a strict doctrinal position. (Sabom, 1998, p. 33)

In my Spiritual Beliefs Questionnaire, I used the statement "Jesus Christ is the Son of God and thus supreme over all other great religious leaders" to separate Christians from nonChristians regardless of their other responses. This was done not only to reflect Jesus' own teaching properly, but, in the words of C. S. Lewis,

to prevent anyone saying the really foolish thing that people often say about Him: "I'm ready to accept Jesus as a great moral teacher, but I don't accept His claim to be God." That is the one thing we must not say. A man who was merely a man and said the sort of things Jesus said would not be a great moral teacher. He would either be a lunatic-on a level with the man who says he is a poached egg-or else he would be the Devil of Hell. You must make your choice. Either this man was, and is, the Son of God; or else a madman or something worse. You can shut Him up for a fool; you can spit at Him and kill Him as a demon; or you can fall at His feet and call Him Lord and God. But let us not come with any patronizing nonsense about His being a great human teacher. He has not left that open to us. He did not intend to. (Lewis, 1960, pp. 55-56)

Ellwood forcefully ends her commentary on Light \& Death by asserting: "Those of us who have faith that beyond the void is Eternal Love, and that elusive transcendent truth is always ready to break through into our worlds, have the right to support and continue creating a world that reflects this faith." Her "right" is not in dispute. But as these "creations" continue to emerge from near-death studies, "as waters boil up from a vast, full spring, so does an immense crowd of gods flow forth from the human mind, while each one, in wandering about with too much license, wrongly invents this or that about God himself" (Calvin, quoted in McNeill, 1960, p. 65). "Eternal love" awaits some, but "the highway to hell is broad; and its gate wide" (Matthew 7:13). As unpopular as it is in this postmodern age, there is only one God and one truth, and His truth is revealed in the Bible. Without this, all yardsticks lose their measure and "[w]e become like an ant trapped upon 
a hanging Christmas ornament:... we cannot see our way out. So we stop, we reach into the air, we feel blindly" and completely miss the real reason the ornament was hung in the first place.

\section{References}

Abanes, R. (1994). Embraced by the light and the Bible. Camp Hill, PA: Horizon Books.

Abanes, R. (1996). Journey into the light: Exploring near-death experiences. Grand Rapids, MI: Baker Books.

Ankerberg, J., and Weldon, J. (1993). The coming darkness. Eugene, OR: Harvest House. Ankerberg, J., and Weldon, J. (1997). The reliability of the Bible. Eugene, OR. Harvest House.

Blomberg, C. (1987). The historical reliability of the Gospels. Downers Grove, IL: InterVarsity Press.

Craig, W. (1981). The Son rises: Historical evidence for the resurrection of Jesus. Chicago, IL: Moody Press.

Craig, W. (1993). Christianity: Where does the evidence point? Grand Rapids, MI: Zondervan [Videocassette].

Geldenhuys, N. (1988). The Gospel of Luke. Grand Rapids, MI: Wm. B. Eerdmans.

Grellner, W., and Krull, F. (1996). [Unusual motivation in double suicide of a lesbian couple. Phenomenology, psychodynamics and influence of contemporary values]. Archiv fur Kriminologie, 198(3-4), 65-72.

Habermas, G. (1988). The verdict of history. Nashville, TN. Thomas Nelson.

Habermas, G. (1996). The historical Jesus. Joplin, MO: College Press.

Lewis, C. S. (1960). Mere Christianity. New York, NY: Macmillan-Collier.

McNeill, J. T. (Ed.). (1960). Calvin Institutes of the Christian religion. Philadelphia, PA: Westminister John Knox Press.

McNicholas, D. (1995, January). In the Light: The Alternative Healing Lifestyles Magazine. Phoenix, AZ: MSG Consulting Group, pp. 3 and 6.

Metzger, B. (1992). The text of the New Testament. New York, NY: Oxford University Press.

Monroe, R. (1973). Journeys out of the body. Garden City, NY: Anchor/Doubleday.

Moody, R. (1980). Comments on "The reality of death experiences: A personal perspective" by Ernst Rodin. Journal of Nervous and Mental Disease, 168, 264-265.

Moody, R. (1997). The last laugh: A new philosophy of near-death experiences, apparitions, and the paranormal. Atlanta, GA. William Moore, Consulting.

Moody, R. (1999). The last laugh: A new philosophy of near-death experiences, apparitions, and the paranormal. Charlottesville, VA: Hampton Roads.

Moody, R., and Perry. P. (1993). Reunions: Visionary encounters with departed loved ones. New York, NY: Villard.

Morris, L. (1971). The Gospel according to John. Grand Rapids, MI: Wm. B. Eerdmans.

Mounce, R. (1977). The book of Revelation. Grand Rapids, MI: Wm. B. Eerdmans.

Pringle, W. (Ed.). (1996). Commentary: Harmony of the evangelists, Matthew, Mark, and Luke, by John Calvin, Vol. 1. Grand Rapids, MI: Baker Book House.

Rawlings, M. (1993). To hell and back: Life after death-Starting new evidence. Nashville, TN: Thomas Nelson.

Reed, J. D. (1999, October 25). Across the great divide. People Magazine, p. 120

Ring, K. (1980). Psychologist comments on the need to keep religious bias out of neardeath research. Anabiosis [East Peoria], 2(1), 14-16.

Ring, K. (1992). The omega project: Near-death experiences, UFO encounters, and mind at large. New York, NY: William Morrow.

Ring, K. (2000). Religious wars in the NDE movement: Some personal reflections on Michael Sabom's Light \& death. Journal of Near-Death Studies, 18, 215-244. 
Sabom, M. (1996). [Review of To hell and back: Life after death-Starting new evidence] Journal of Near-Death Studies, 14, 197-209.

Sabom, M. (1998). Light \& death: One doctor's fascinating account near-death experiences. Grand Rapids, MI: Zondervan.

Sabom, M. (2000). Response to Kenneth Ring's "Religious wars in the NDE movement: Some personal reflections on Michael Sabom's Light \& death." Journal of Near-Death Studies, 18, 245-271.

Scharfetter, C. (1998). [Occultism, parapsychology and the esoteric from the perspective of psychopathology]. Fortschrifte der Neurologie-Psychiatrie, 66, 474-82.

Sheler, J. (1999). Is the Bible true? San Francisco, CA: HarperSanFrancisco.

Sproul, R. C. (1996). Now, that's a good question! Wheaton, IL: Tyndale House.

Strieber, W. (1987). Communion: A true story. New York, NY: Avon.

Strobel, L. (1998). The case for Christ. Grand Rapids, MI: Zondervan.

Vollmoeller, W. (1994). [Mediumistic psychoses, a case report]. Nervenarzt, 65(e): 57-61.

Wilkins, M. J., and Moreland, J. P. (1995). Jesus under fire. Grand Rapids, MI: Zondervan. 